\title{
Hubungan penyakit jantung bawaan pada anak dengan status pendidikan orang tua
}

\author{
${ }^{1}$ Kimberly Munaiseche \\ ${ }^{2}$ Rocky Wilar \\ ${ }^{2}$ Erling D. Kaunang
}

\author{
${ }^{1}$ Kandidat Skripsi Fakultas Kedokteran Universitas Sam Ratulangi Manado \\ ${ }^{2}$ Bagian Pediatri Fakultas Kedokteran Universitas Sam Ratulangi Manado \\ Email: kimberly.munaiseche@gmail.com
}

\begin{abstract}
Congenital heart disease (CHD) has an incidence of $30 \%$ of all congenital abnormalities. The incidences of CHDs in developed countries and developing countries range from 6-10 cases per 1000 live births, with an average of 8 per 1,000 live births. Education and knowledge of parents play important roles in the treatment of CHD. This study was aimed to determine the relationship between CHD in children and the educational status of parents. This was an analytical observational study with a cross sectional design. Subjects were all children admitted to the Pediatrics Department Prof. Dr. R. D. Kandou Manado in 2014-2015 due to heart diseases. Data consisted of sex, age, and the last education of the parents. Data were analyzed by using the Chi-Square test. The results showed that there were 100 children with heart diseases consisted of 53 males and 47 females. There were 38 males $(52.8 \%)$ with positive CHD and the highest percentage of positive CHD was at 7-12 years as many as 17 children (60.7\%). Based on education level, most of the children's fathers were senior high school (42.9\%) as well as the children's mother $(53.6 \%)$. The Chi-Square showed $\mathrm{p}=0.776$ and $\mathrm{p}=0.532$ for the relationships between the fathers' as well as the mothers' education levels and congenital heart disease in children. Conclusion: There was no significant relationship between parents' educational level and congenital heart disease in children.
\end{abstract}

Keywords: congenital heart disease, education.

\begin{abstract}
Abstrak: Penyakit jantung bawaan (PJB) merupakan kelainan bawaan yang sering dijumpai, dengan angka kejadian 30\% dari seluruh kelainan bawaan. Insiden PJB dinegara maju maupun negara berkembang berkisar 6-10 kasus per 1000 kelahiran hidup, dengan rata-rata 8 per 1000 kelahiran hidup. Pendidikan, pengetahuan, dan pekerjaan orang tua berperan penting dalam penanganan PJB. Penelitian ini bertujuan untuk mengetahui adanya hubungan antara PJB pada anak dengan status pendidikan orang tua. Jenis penelitian ialah analitik observasional dengan desain potong lintang. Subjek penelitian ialah semua anak dengan penyakit jantung yang dirawat di Instalasi Rawat Inap di Bagian Ilmu Kesehatan Anak RSUP Prof. Dr. R. D. Kandou Manado tahun 2014-2015. Data diambil dari Bagian Rekam Medik berupa jenis kelamin anak, usia anak, serta pendidikan terakhir ayah dan ibu. Analisis data dilakukan dengan uji Chi-Square. Hasil penelitian mendapatkan jumlah subjek penelitian sebanyak 100 anak terdiri dari 53 anak laki-laki dan 47 anak perempuan. Berdasarkan jenis kelamin yang terbanyak positif PJB ialah laki-laki sebanyak 38 orang $(52,8 \%)$. Berdasarkan usia yang terbanyak positif PJB ialah 7-12 tahun sebanyak 17 anak $(60,7 \%)$. Pendidikan terbanyak ialah SLTA yaitu pada ayah $42,9 \%$ dan pada ibu sebesar $53,6 \%$. Uji Chi-Square, mendapatkan $\mathrm{p}=0,776$ dan $\mathrm{p}=0,532$ untuk hubungan tingkat pendidikan ayah dan ibu dengan PJB. Simpulan: Tidak terdapat hubungan bermakna antara tingkat pendidikan orang tua dengan penyakit jantung bawaan pada anak.
\end{abstract}

Kata kunci: penyakit jantung bawaan, pendidikan 
Penyakit jantung bawaan (PJB) merupakan kelainan bawaan yang sering dijumpai, dengan angka kejadian 30\% dari seluruh kelainan bawaan. ${ }^{1}$ Insiden PJB dinegara maju maupun Negara berkembang berkisar 6-10 kasus per 1000 kelahiran hidup, dengan rata-rata 8 per 1000 kelahiran hidup. Diperkirakan satu juta anak di Amerika hidup dengan PJB. ${ }^{2-3}$ Angka kejadian PJB di Indonesia ialah 8 tiap 1000 kelahiran hidup. Berdasarkan profil Kesehatan Indonesia 2008, angka kejadian penyakit jantung dan pembuluh darah di Indonesia cenderung meningkat dan dapat menyebabkan gangguan tumbuh kembang, kecacatan dan kematian. ${ }^{4}$ Menurut Perhimpunan Dokter Spesialis Kardiovaskuler Indonesia (PERKI), PJB menempati peringkat pertama diantara penyakit-penyakit lain yang menyerang bayi. ${ }^{3}$ Pada penelitian sebelumnya di RSUP Prof. R. D. Kandou Manado, didapatkan 79 pasien PJB terdiri dari 43 laki-laki $(54,43 \%)$ dan 36 perempuan (45,56\%). Sebagian besar $(94,93 \%)$ dengan asianotik. Diagnosis yang paling banyak ialah Atrial Septal Defect (ASD) sebanyak 56,96\%, Ventricle Septal Defect (VSD) 25,31\%, Patent Ductus Arteriosus (PDA) 8,87\%, Tetralogy of Fallot (ToF) 5,06\%, dan Atrioventricle Septal Defect (AVSD) $3,7 \%{ }^{5}$

PJB tidak mudah dideteksi karena hanya $30 \%$ yang memberikan gejala pada minggu-minggu awal kehidupan dan 30\% pada masa neonatal tetapi bila tidak dideteksi dan ditangani secara tepat dapat menyebabkan kematian pada bulan pertama kehidupan. ${ }^{6}$ Dengan ekokardiografi fetal, telah dapat dideteksi defek jantung, distrimia serta disfungsi miokard pada masa janin. Di bidang pencegahan terhadap timbulnya gangguan organogenesis jantung pada masa janin, sampai saat ini masih belum memuaskan, walaupun sudah dapat diindentifikasi adanya multifaktor yang saling berinteraksi yaitu faktor genetik dan lingkungan. $^{2}$

Penatalaksanaan anak PJB harus dilaksanakan secara menyeluruh yaitu meliputi penanganan komprehensif holistik yang mencakup aspek preventif, promotif, kuratif, dan rehabilitatif. ${ }^{7}$ Seiring dengan kemajuan ilmu pengetahuan dan teknologi, tindakan bedah dan non-bedah sebagai upaya kuratif dan rehabilitatif makin maju dan makin banyak dilakukan, namun angka kematian di Indonesia karena PJB masih tetap tinggi. ${ }^{8}$ Hal ini mungkin disebabkan kurangnya fasilitas, tingginya biaya, dan kurangnya kemampuan finansial orangtua pasien PJB. Selain itu kurangnya pengetahuan orangtua, pendidikan rendah, dan lingkungan yang tidak mendukung juga mempersulit penanganan pada pasien PJB. ${ }^{8}$

Pengetahuan orangtua merupakan salah satu hal yang esensial dalam penanganan PJB. Pasien PJB ialah anakanak yang masih belum dapat mengurus kebutuhan kesehatannya sendiri. Kurangnya pengetahuan orangtua memengaruhi persepsi terhadap penyakit yang ada. Menurut penelitian Adhikarmika, sebagian besar orangtua dari anak dengan PJB tidak memiliki pengetahuan yang baik tentang PJB itu sendiri, ${ }^{10}$ padahal pemahaman yang baik dari orangtua pasien PJB terbukti dapat meningkatkan kepatuhan orangtua, mengurangi kecemasan pada anak dan juga orangtuanya yang berakibat baik terhadap kemajuan kesehatan anaknya. $^{9-10}$

Memahami dan menjelaskan tentang PJB bukanlah hal yang mudah bagi banyak dokter keluarga dan dokter anak, terlebih lagi bagi orangtua yang tidak memiliki latar belakang medis. ${ }^{9}$ Oleh karena itu diperlukan suatu upaya untuk meningkatkan pengetahuan tentang PJB tidak hanya pada orangtua anak pasien PJB tetapi lebih luas yaitu pada masyarakat secara umum sehingga diharapkan dapat membantu dalam upaya promotif, preventif, dan deteksi dini PJB. ${ }^{10}$ Baik pendidikan orang tua pasien maupun pekerjaan juga merupakan faktor yang berpengaruh terhadap pengetahuan orangtua pasien tentang PJB. ${ }^{9-11}$ Orangtua sebagai bagian yang paling dekat dengan anak, diharapkan mempunyai pengetahuan yang cukup serta sikap yang mendukung sehingga akan terbentuk perilaku kesehatan yang menunjang perawatan anak PJB. 
Data mengenai pengetahuan orangtua secara umum tentang penyakit jantung bawaan serta status pendidikan orangtua pasien belum banyak diteliti. Tujuan penelitian ini untuk mengetahui hubungan penyakit jantung bawaan dengan status pendidikan orangtua.

\section{BAHAN DAN METODE PENELITIAN}

Jenis penelitian yang dilakukan ialah analitik observasional dengan desain potong lintang. Penelitian dilakukan di Bagian Ilmu Kesehatan Anak FK UNSRAT RSUP Prof. Dr. R. D. Kandou Manado. Populasi penelitian mencakup seluruh pasien anak yang dirawat di Instalasi Rawat Inap di Bagian Ilmu Kesehatan Anak FK UNSRAT RSUP Prof. Dr. R. D. Kandou Manado. Sampel dipilih sesuai kriteria inklusi yaitu semua anak berusia $<18$ tahun dengan penyakit jantung.

Data yang dikumpulkan meliputi: jenis kelamin, usia anak, status pendidikan orangtua dari anak dengan PJB yang diambil dari rekam medik di Bagian Ilmu Kesehatan Anak RSUP Prof. Dr. R. D. Kandou. Data disajikan berupa tabel dan dianalisis menggunakan program SPSS 22.

\section{HASIL PENELITIAN}

Tabel 1 menjelaskan distribusi jenis kelamin anak dengan penyakit jantung.

Tabel 1. Karakteristik sampel berdasarkan jenis kelamin dengan PJB

\begin{tabular}{lcccc}
\hline Jenis & \multicolumn{2}{c}{ PJB } \\
kelamin & \multicolumn{2}{c}{ Negatif } & \multicolumn{2}{c}{ Positif } \\
& $\mathrm{n}$ & $\%$ & $\mathrm{n}$ & \% \\
\hline Laki-laki & 15 & 53,6 & 38 & 52,8 \\
Perempuan & 13 & 46,4 & 34 & 47,2 \\
Total & 28 & 100,0 & 72 & 100,0 \\
\hline
\end{tabular}

Sampel berjenis kelamin laki-laki yang negatif PJB sebanyak 15 anak $(53,6 \%)$ dan yang positif PJB sebanyak 38 anak $(52,8 \%)$. Sampel berjenis kelamin perempuan yang negatif PJB sebanyak 13 anak $(46,4)$ dan yang positif PJB sebanyak 34 anak $(47,2)$. Jumlah total sampel sebanyak
100 anak dan didapatkan yang terbanyak ialah laki-laki yang positif PJB,

Tabel 2 menjelaskan distribusi berdasarkan usia anak. Terdapat 28 pasien yang negatif PJB dengan usia $<1$ tahun sebanyak 1 anak (3,6\%), usia 1-6 tahun sebanyak 5 anak (17,9\%), usia 7-12 tahun sebanyak 17 anak $(60,7 \%)$, dan usia 13-18 tahun sebanyak 5 anak $(17,9 \%)$. Terdapat 72 pasien yang positif PJB dengan usia <1 tahun sebanyak 20 anak $(27,8 \%)$, usia 1-6 tahun sebanyak 28 anak (38,9\%), usia 7-12 tahun sebanyak 22 anak $(30,6 \%)$, dan usia 13-18 tahun sebanyak 2 anak (2,8\%).

Tabel 2. Karakteristik sampel berdasarkan umur dengan PJB

\begin{tabular}{lcccc}
\hline \multirow{2}{*}{ Usia (tahun) } & \multicolumn{4}{c}{ Anak PJB } \\
& Negatif & \multicolumn{2}{c}{ Positif } \\
& $\mathrm{n}$ & $\%$ & $\mathrm{n}$ & $\%$ \\
\hline$<1$ tahun & 1 & 3,6 & 20 & 27,8 \\
$1-6$ tahun & 5 & 17,9 & 28 & 38,9 \\
$7-12$ tahun & 17 & 60,7 & 22 & 30,6 \\
13-18 tahun & 5 & 17,9 & 2 & 2,8 \\
Total & 28 & 100 & 72 & 100 \\
\hline
\end{tabular}

Tabel 3 menjelaskan karakteristik sampel berdasarkan hubungan antara tingkat pendidikan ayah SD yang negatif sebanyak 2 orang $(7,1 \%)$, SMP berjumlah 6 orang $(21,4 \%)$, SLTA berjumlah 12 orang $(42,9 \%)$, diploma berjumlah 1 orang $(3,65 \%)$, dan S1/S2 berjumlah 7 orang $(25,0 \%)$. Pada tingkat pendidikan ayah dari anak penderita yang positif PJB, tingkat SD berjumlah 2 orang $(7,1 \%)$, SMP berjumlah 13 orang $(18,1 \%)$, SLTA berjumlah 38 orang $(52,8 \%)$, Diploma berjumlah 5 orang $(6,5 \%)$, dan S1/S2 berjumlah 14 orang $(19,4 \%)$.

Hubungan antara tingkat pendidikan ayah dan PJB diuji dengan Uji $x^{2}$. Hasil uji ini tidak digunakan sebab expected count sebesar 40,0\% kurang dari 5 (seharusnya hanya 20\%). Oleh sebab itu digunakan analisis koefisien korelasi Gamma (data kedua variabel bentuk kategori ordinal/data bertingkat). Hasil analisis ini diperoleh $r_{\text {gamma }}=0,053$ dengan $\mathrm{p}=0,0776$ yang 
menyatakan tidak ada hubungan bermakna antara tingkat pendidikan ayah dengan PJB (Tabel 3).

Tabel 4 menjelaskan karakteristik sampel berdasarkan hubungan antara tingkat pendidikan ibu SD yang negatif PJB, tingkat SD berjumlah 2 orang $(7,1 \%)$, SMP berjumlah 2 orang $(7,1 \%)$, SLTA berjumlah 15 orang $(53,6 \%)$, diploma berjumlah 3 orang $(10,7 \%)$, dan S1/S2 berjumlah 6 orang $(21,4 \%)$. Tingkat pendidikan ibu dari anak penderita yang positif PJB, tingkat SD berjumlah 5 orang (6,9\%), SMP berjumlah 7 orang $(9,7 \%)$, SLTA berjumlah 31 orang $(43,1 \%)$, diploma berjumlah 6 orang $(8,3 \%)$, dan S1/S2 berjumlah 23 orang $(31,9 \%)$.

Hubungan antara tingkat pendidikan ibu dan PJB di uji dengan Uji $\mathrm{x}^{2}$. Hasil uji ini tidak digunakan sebab expected count sebesar 30,0\% kurang dari 5 (seharusnya hanya 20\%). Oleh sebab itu digunakan analisis koefisien korelasi Gamma (data kedua variabel bentuk kategori ordinal/data bertingkat). Hasil analisis ini diperoleh $r_{\text {gamma }}=0,106$ dengan $p=0,532$ yang menyatakan tidak ada hubungan yang bermakna antara tingkat pendidikan ayah dengan PJB (Tabel 4).

Tabel 3. Karakteristik sampel berdasarkan pendidikan ayah dari anak dengan PJB

\begin{tabular}{lccclll}
\hline \multirow{2}{*}{ Pendidikan ayah } & \multicolumn{5}{c}{ Negatif } & \multicolumn{2}{c}{ Positif } & \\
& n & $\%$ & n & \% & Uji \\
\hline SD & 2 & 7,1 & 2 & 7,1 & \\
SMP & 6 & 21,4 & 13 & 18,1 & ${ }_{\text {gamma }}=0,053^{*}$ \\
SLTA & 12 & 42,9 & 38 & 52,8 & $\mathrm{p}=0,776$ \\
Diploma & 1 & 3,6 & 5 & 6,5 & \\
S1/S2 & 7 & 25,0 & 14 & 19,4 & \\
Total & 28 & 100,0 & 72 & 100,0 & \\
\hline *Diuji dengan korelasi Gamma & & & \\
\end{tabular}

Tabel 4. Distribusi sampel berdasarkan pendidikan ibu dari anak dengan PJB

\begin{tabular}{|c|c|c|c|c|c|}
\hline \multirow{3}{*}{ Pendidikan ibu } & \multicolumn{4}{|c|}{ Anak PJB } & \multirow[b]{3}{*}{ Uji } \\
\hline & \multicolumn{2}{|c|}{ Negatif } & \multicolumn{2}{|c|}{ Positif } & \\
\hline & $\mathbf{n}$ & $\%$ & $\mathbf{n}$ & $\%$ & \\
\hline $\mathrm{SD}$ & 2 & 7,1 & 5 & 9 & \\
\hline SMP & 2 & 7,1 & 7 & 9,7 & $r_{\text {gamma }}=0,106^{*}$ \\
\hline SLTA & 15 & 53,6 & 31 & 43,1 & $p=0,532$ \\
\hline Diploma & 3 & 10,7 & 6 & 8,3 & \\
\hline $\mathrm{S} 1 / \mathrm{S} 2$ & 6 & 21,4 & 23 & 31,9 & \\
\hline Total & 28 & 100,0 & 72 & 100,0 & \\
\hline
\end{tabular}

*Diuji dengan korelasi Gamma

\section{BAHASAN}

Penelitian ini dilakukan di Bagian Ilmu Kesehatan Anak FK UNSRAT RSUP Prof. Dr. R. D. Kandou Manado periode tahun 2014-2015. Didapatkan total sampel berjumlah 100 anak penderita penyakit jantung bawaan di RSUP Prof. Dr. R. D.
Kandou Manado yang sesuai kriteria inklusi peneliti didapatkan 53 anak berjenis kelamin laki-laki dan 47 anak berjenis kelamin perempuan. Semua data sampel diambil dari data sekunder, yaitu data rekam medik dari Januari 2014 sampai Desember 2015. 
Hubungan antara tingkat pendidikan ayah dan PJB di uji dengan Uji $x^{2}$. Hasil uji ini tidak digunakan sebab expected count sebesar 40,0\% kurang dari 5 (seharusnya hanya 20\%). Oleh sebab itu digunakan analisis koefisien korelasi Gamma (data kedua variabel bentuk kategori ordinal/data bertingkat). Hasil analisis ini diperoleh $r_{\text {gamma }}=0,053$ dengan $p=0,0776$. Hasil ini menyatakan tidak ada hubungan yang bermakna antara tingkat pendidikan ayah dengan PJB ( $p=0,0776)$.

Hubungan antara tingkat pendidikan ibu dan PJB du uji dengan Uji $x^{2}$. Hasil uji ini tidak digunakan sebab expected count sevesar 30,0\% kurang dari 5 (seharusnya hanya 20\%). Oleh sebab itu digunakan analisis koefisien korelasi Gamma (data kedua variabel bentuk kategori ordinal/data bertingkat). Hasil analisis ini diperoleh $r_{\text {gamma }}=0,106$ dengan $p=0,532$. Hasil ini menyatakan tidak ada hubungan yang bermakna antara tingkat pendidikan ayah dengan PJB ( $\mathrm{p}=0,532)$.

Studi di negara maju dan berkembang menunjukkan bahwa insidens PJB berkisar 6 sampai 10 per 1000 kelahiran hidup dengan rerata 8 per 1000 kelahiran hidup. Yang nampak berbeda ialah jenis PJB di rumah sakit rujukan oleh karena di negara maju praktis semua pasien telah dapat dideteksi dalam masa bayi bahkan pada masa neonatus, sedangkan di negara berkembang masih banyak yang dibawa berobat setelah anak besar. Bila dilakukan pengelompokan kasus menurut terdapatnya sianosis atau tidak, maka pada saat diagnosis persentase pasien pada setiap kelompok usia hampir sama, kecuali pada masa neonatus (pada kelompok sianotik $12,1 \%$ sedang kelompok non-sianotik 3,9\%). Cukup banyak juga pasien yang didiagnosis setelah usia 5 tahun, yakni sekitar $17 \%$ bahkan lebih kurang $7 \%$ kasus pada kedua kelompok diagnosisnya ditegak-kan setelah anak berusia 10 tahun yang biasanya menderita kelainan relatif 'ringan'. Defek septum ventrikel merupakan PJB terbanyak, yakni 33,1\% dari seluruh pasien dengan PJB.

Pada penelitian sebelumnya yang dilakukan oleh Rahmi, pengetahuan tidak berhubungan bermakna dengan perilaku orang tua terhadap anak dengan PJB. Persentase terbesar dari pengetahuan orang tua tentang PJB terdapat pada kategori sedang $(86,7 \%)$. Hal ini sesuai dengan tingkat pendidikan orang tua sebagian besar (37\%) yang berada pada tingkat pendidikan yang cukup rendah, yaitu SD. Kemampuan untuk menyerap suatu pengetahuan akan semakin baik dengan tingkat pendidikan yang lebih tinggi pula. Semua responden belum pernah mengetahui tentang istilah PJB sebelum anaknya didiagnosis menderita PJB oleh dokter. Hal ini menunjukkan kurangnya pengetahuan masyarakat awam tentang PJB.

Hasil penelitian ini sejalan dengan yang diungkapkan oleh Notoatmodjo bahwa pada situasi tertentu, stimulus dapat langsung menimbulkan tindakan artinya seseorang dapat bertindak atau berperilaku baru tanpa mengetahui terlebih dulu makna stimulus yang diterimanya, sehingga tindakan seseorang tidak harus didasari oleh pengetahuan atau sikap. kepercayaan, tradisi, keterjangkauan fasilitas, adanya pengaruh orang lain yang disegani, dapat menjadi faktor-faktor yang mendukung terbentuknya perilaku yang baik.

Tidak terdapatnya hubungan bermakna antara tingkat pendidikan orang tua, pengetahuan orang tua dengan upaya pencarian bantuan, pengambilan keputusan dalam melaksanakan tindakan medik yang diambil dokter, pengetahuan orang tua mengenai pemberian gizi, dan pelaksanaan imunisasi pada anak dengan PJB.

Hal ini dapat disebabkan oleh banyak faktor. Penelitian tentang hubungan antara PJB pada anak dengan status pendidikan orang tua belum banyak dilakukan. Penelitian ini masih terfokus pada seberapa besar pengetahuan orang tua terhadap PJB yang diderita anak.

Berdasarkan variabel dan pendidikan ibu tidak didapati hubungan bermakna antara PJB dengan status pendidikan orang tua. Hal ini disebabkan kurangnya fasilitas, tingginya biaya dan kurangnya finansial orang tua pasien PJB yang mempersulit penanganan pasien PJB. 


\section{SIMPULAN}

Berdasarkan hasil penelitian dan bahasan dapat disimpulkan bahwa penyakit jantung bawaan tidak berhubungan dengan status pendidikan orang tua.

\section{SARAN}

Perlu diadakan penelitian lanjutan mengenai hubungan status pendidikan orang tua dengan variasi karakteristik dan lokasi yang lebih luas sehingga dapat menambah informasi mengenai tingkat pengetahuan PJB dan selanjutnya menjadi masukan dalam penyebaran informasi PJB.

\section{DAFTAR PUSTAKA}

1. Wisnuwardhana M. Manfaat pemberian diet terhadap pertumbuhan pada anak dengan penyakit jantung bawaan [Disertasi]. Semarang: Universitas Diponegoro; 2006

2. Lewis A, Hsieh V. Congenital heart disease and lipid disorders in children. Pediatric Nutrition (2nd ed), 2005.

3. Roebiono PS. Diagnosis dan tatalaksana penyakit jantung bawaan [internet]. Available from: http://repository. ui.ac.id/contents/koleksi/11/68321669 235fd5a14595241e85893e6bbb8907f 2.pdf.

4. Penyakit jantung bawaan, Angka tinggi dengan tenaga terbatas [internet]. 2010. Available from: http://www.inaheart.org/index.php/ public/information/news.detail/12

5. Okoromah CAN, Ekure EN, Lesi FEA, Okunowo WO, Tijani BO, Okeiyi JC. Prevalence, profile and predirectors of malnutrition in children with congenital heart defects: a case-control observational study. Arch Dis Child. 2011;96(4):354-60.

6. Rahman MA, Ontoseno T. Deteksi dini penyakit jantung bawaan pada neonatus: diagnosis dan saat rujukan. [homepage on the internet]. 2006 [cited 2011 Sept 12]. Available from: http://www.pediatrik.com/buletin/200 60220-f18q56-buletin.pdf

7. Departemen Kesehatan RI. Rencana pembangunan jangka panjang bidang kesehatan tahun 2005-2025 [homepage on the Internet]. c2009. [updated 2009 Jan 29; cited 2010 Jan 31]. Available from:

http://www.depkes.go.id/downloads/n ewdownloads/rancangan_RPJPK_200 5-.pdf

8. Rahajoe AU. Management of patients with congenitally malformed hearts in Indonesia. Cardiol Young. 2007; 17(6):584-8.

9. Berry M, Haramati Z, Rein JJTA, Nir A. Parental knowledge and views of pediatric congenital heart disease. Isr Med Assoc J. 2001;393:194-7.

10.Apriandari A. Perbedaan pengetahuan tentang penyakit jantung bawaan antara orangtua pasien di Pusat Pelayanan Kesehatan Primer dan Tertier [Undergraduate thesis]. Semarang: Fakultas Kedokteran Universitas Diponegoro; 2010.

11. Cheuk DKL, Wong SMY, Choi YP, Chau AKT, Cheung YF. Parents' understanding of their child's congenital heart disease. Heart BMU. 2004;90(4):435-9. 